\title{
Experience of Producing Natural Gas from Corn Straw in China
}

Hansi Liu ${ }^{\mathrm{a}}$, Xunmin $\mathrm{Ou}^{\mathrm{a}, *}$, Jiehui Yuan ${ }^{\mathrm{a}}$, Xiaoyu Yan ${ }^{\mathrm{b}, *}$

3

${ }^{\mathrm{a}}$ Institute of Energy, Environment and Economy, Tsinghua University, Beijing 100084, China

$4 \quad{ }^{\mathrm{b}}$ Environment and Sustainability Institute, University of Exeter Penryn Campus, Penryn, Cornwall TR10 9FE, UK

$5 *$ Corresponding authors; E-mail: ouxm@mail.tsinghua.edu.cn (Prof. OU); Xiaoyu.Yan@ exeter.ac.uk

6 (Dr. YAN)

7 Tel.: +86-10-62772758; Fax: +86-10-62796166.

8 


\section{Experience of Producing Natural Gas from Corn Straw in China}

anstitute of Energy, Environment and Economy, Tsinghua University, Beijing 100084, China

${ }^{\mathrm{b}}$ Environment and Sustainability Institute, University of Exeter Penryn Campus, Penryn, Cornwall TR10 9FE, UK

* Corresponding authors; E-mail: ouxm@ mail.tsinghua.edu.cn (Prof. OU); Xiaoyu.Yan@ exeter.ac.uk (Dr. YAN)

Tel.: +86-10-62772758; Fax: +86-10-62796166.

\section{Abstract}

Globally, crop straw is a rich resource and further establishment of its use as an energy source is an important aspect in developing the circular economy. Projects in this vein can bring benefits such as improving energy access and living conditions as well as boosting the local economy and employment opportunities in rural communities. This paper presents a detailed case study on the production of bionatural gas (BNG) from corn straw in China, using Life Cycle Analysis (LCA) to assess energy consumption and greenhouse gas (GHG) emissions, conducting economic analysis, and analyzing operation management models. The "Nongbaomu" business model (whereby professional personnel assist farmers in the management of straw collection, bundling, storage and transportation) and the "Mutual Offsetting in Kind" business model (whereby farmers can buy a quota of the project's BNG products at a lower price in return for selling straw to the project) can ensure the acquisition of straw by the $\mathrm{BNG}$ project at stable prices and high quality. Because the main product (BNG) replaces refined oil products used by automobiles and the byproduct (organic fertilizer) replaces traditional fertilizer (produced using coal), the project offers the potential for significant decreases (up to 80\%) in life cycle GHG emissions and fossil fuel use. Benefited from the relatively high natural gas prices in the project location and applicable government subsidies, our studied case was found to be economically viable. The findings in this study are also likely to be relevant to other countries where governments should develop industrial policies that support the development of rural distributed energy, and introduce and implement appropriate subsidies to allow BNG to compete in the traditional natural gas market. Although, enterprises are responsible for selecting an effective business models and the most appropriate technological pathway, governments should also identify the ways in which they can support businesses to make these choices.

Keywords: Circular economy; Agricultural waste; Corn straw; Biogas; China; LCA 


\section{Introduction}

\subsection{Global use of straw as an energy source}

\subsubsection{Crop straw resources}

Crop straws are the easily accessible biomass resource. As Table 1 shows, a variety of types of crops are produced around the world with global production of rice, wheat and corn, totaling more than 2,508 million tonnes (Mt) in 2014 (UN, 2017). We can estimate the straw production based on the Residue-toCrop Ratio (RCR) assumption (Cardoen et al., 2015a). RCR is defined as the ratio of the weight of residue generated (e.g., rice straw) to the equivalent weight of agricultural product (e.g., rice grains). Corn straw production in 2014 was about 1,661 Mt, highest among the 3 major types of crop straws.

Table 1. Global annual straw production

\begin{tabular}{llll}
\hline & Crop Production & Residue-to-crop ratio & Straw production \\
\hline Unit & Million tonnes & & Million tonnes \\
Rice & $740.96^{1}$ & $1.5^{2}$ & $1,111.44$ \\
Wheat & $728.96^{1}$ & $1.65^{2}$ & $1,202.78$ \\
Corn & $1038.28^{1}$ & $1.6^{2}$ & $1,661.25$ \\
\hline
\end{tabular}

Note: ${ }^{1}$. UN (2017). ${ }^{2}$. Cardoen et al. (2015a).

\subsubsection{Current straw usage}

Currently, straw is mainly used as animal feed or directly mixed into the soil as a natural fertilizer. The resource may also be burned directly, though this can have severe environmental impacts and is not consistent with the circular economy. Decentralized residue utilization technologies like biogas production can provide energy and fertilizer in a relatively clean way (Cardoen et al., 2015b). Although the amount of the resource used to produce biogas is small, this application has been growing relatively rapidly in recent years (Zeng et al., 2007). This is because producing biogas from straw can be an efficient way to replace fossil fuels in a more cost-effective manner than other technologies (Pohl et al., 2012) and end-use energy efficiency of biogas use is also relatively high, though influenced by many factors (Gerardi, 2003; Nordlander et al., 2012).

\subsubsection{Opportunities and challenges of straw as an energy source}

(1) Promoting distributed energy and energy access in rural areas

Access to energy is severely limited in many rural areas around the world, where the use of local crop straws in distributed energy projects could have a large impact. Previous work conducted from an energy-planning perspective (Hiremath et al., 2007; Kumar et al., 2003) notes that distributed energy can be particularly useful in alleviating environmental, economic and social inequalities in rural areas. 
For example, Fernandez et al. (2005) calculated the energy consumption inequality in India using econometric methods and showed that distributed energy in rural areas has important social significance. Taking a different approach, a number of studies have highlighted that problems in supplying electricity stem from the disconnect between centralized energy production and decentralized use (especially in rural areas). In particular, rural communities suffer from inadequate grid coverage, poor electricity quality or reliability. With little economic incentives to improve these issues for a centralized grid, these studies (Gao et al., 2014; Xi et al., 2013; Zhang et al., 2010) conclude that distributed energy systems using local biomass as feedstock are a feasible option for resolving energy access issues. Crop straw is therefore an important resource in rural distributed energy systems (see Figure 1) and can improve energy access in rural areas.

\section{(2) Promoting the coordinated development of a rural economy and environmental governance}

In many countries, the income gap between urban and rural residents is relatively large (Lu et al., 2004; Munish et al., 2015; Sahn et al., 2003). For example, the average incomes of urban and rural residents in China in 2015 were RMB 31,200 and 9,221 (US\$ 4,588 and 1,356 based on a RMB/USD exchange rate of 6.8 on 16 June 2017), respectively (National Statistics Bureau of China, 2016). Developing the rural economy and providing employment for farmers are important tasks for developing countries. Rural energy development based on locally produced straw could increase investment and promote the local economy as farmers can sell their straw for productive uses. In China, approximately RMB 5.5 billion ( US\$ 0.8 billion) was invested in 2015 in biogas projects with a total of RMB 38.6 billion ( US\$ 5.7 billion) invested in rural biogas projects from 2011 to 2015 (Guo, 2014). Biogas development is also important for employment and 2.74 million people are employed in the bioenergy sector by 2016 (ARENA, 2015).

Lots of crop straw resource is simply abandoned globally, occupying arable land, affecting the local environment, and creating a fire hazard. Some is even disposed of by open burning, resulting serious haze, soil mineralization and other environmental and social impacts such as delaying flights and increasing the risk of traffic accidents (Guo, 2014). Thus, utilizing straw as energy use can promote the coordinated development of a rural economy and environmental governance.

\section{(3) Few success stories have been reported for the energy use of crop straws}

A variety of reasons, including a lack of skilled labor, changes in technology and relative inconvenience in use, have caused the number of household-scale biogas projects to begin to decline in many countries including China ( $\mathrm{Li}, 2015)$. At the same time, there are few successful straw-fed biogas projects that have been reported, though recent years have also seen an increase in the use of straw in large-scale centralized projects both in China and globally. 
Key operational challenges faced by straw-fueled projects have been reported to include collection of the dispersed resource, acquiring straw resources at a stable price, competition with high quality resources used for direct combustion and gasification electricity generation projects, and many technical bottlenecks including imperfect ancillary equipment for raw material pretreatment, raw material transportation and mixing, and biogas purification and storage (Li, 2015).

\section{(4) Many straw-based energy projects are not cost-effective}

The challenging economic viability of many straw projects requires that they run at full load and receive government subsidies. In practice, this often means that projects suffer losses following changes in the costs of raw materials or inputs, or because of unplanned outages (Huang, 2016). Raw material costs (and therefore project economics) in particular can be strongly affected by their security of supply, which depends on the area from which the material is sourced and the transport costs and level of competition within the area.

\subsection{Developments of biogas production, straw resource and usage in China}

\subsubsection{Development of biogas production in China}

China's biogas projects have been developing rapidly in recent years, as shown in Table 2. As of 2015, China had 42 million household-scale and 80,500 large-scale projects. Annual production from the large projects was 15.2 billion cubic meters of biogas or $12 \mathrm{Mt}$ of coal equivalent (Mtce). There were 110,975 biogas projects of various types with a total fermenting tank capacity of more than 18.93 million cubic meters (Tian, 2016).

Table 2. Development of household and centralized biogas systems in China

\begin{tabular}{cccccc}
\hline Item & Unit & $\mathbf{2 0 0 0}$ & $\mathbf{2 0 0 5}$ & $\mathbf{2 0 1 0}$ & $\mathbf{2 0 1 5}$ \\
\hline $\begin{array}{c}\text { Household biogas volume } \\
\text { Annual gas production of } \\
\text { household biogas } \\
\text { Total pool capacity of } \\
\text { concentrated biogas }\end{array}$ & $\begin{array}{c}\text { million } \\
\text { households } \\
\text { billion } \\
\text { cubic meters } \\
\text { million } \\
\text { cubic meters }\end{array}$ & 8.48 & 18.07 & 38.51 & 41.93 \\
\hline
\end{tabular}

Note: Tian (2016).

\subsubsection{Straw resource and usage in China}

\section{(1) Uses of biomass energy resources}

In China, biomass resources are consumed by a number of energy production processes, including those that produce electricity, heat, gas and liquid fuels, as shown in Table 3. The current annual consumption of 34 Mtce has the potential to grow significantly given that this represents only $7.6 \%$ of the 460 Mtce of biomass resources available (Han et al., 2016). According to the Renewable Energy 
Table 3. Production and consumption of biomass-based energy in China in 2015

\begin{tabular}{|c|c|c|c|c|c|}
\hline \multirow{2}{*}{ Utilization method } & \multicolumn{2}{|c|}{ Utilization scale } & \multicolumn{3}{|c|}{ Annual output } \\
\hline & Quantity & Unit & Quantity & Unit & $\begin{array}{l}\text { Measured in } \\
\text { Mtce }\end{array}$ \\
\hline $\begin{array}{c}\text { Biomass electricity } \\
\text { generation }\end{array}$ & 10 & million $\mathrm{kW}$ & 43 & billion $\mathrm{kWh}$ & 13.76 \\
\hline $\begin{array}{c}\text { Household biogas } \\
\text { Large-scale biogas project } \\
\text { Biogas capacity } \\
\end{array}$ & $\begin{array}{c}50 \\
80.5 \\
200\end{array}$ & $\begin{array}{c}\text { million } \\
\text { households } \\
\text { Thousand } \\
\text { million cubic } \\
\text { meters } \\
\end{array}$ & 15.2 & $\begin{array}{l}\text { billion cubic } \\
\text { meters }\end{array}$ & 12.00 \\
\hline Biomass forming fuels & 10 & million tons & & & 5.00 \\
\hline Biofuel ethanol & & & 2.3 & $\mathrm{Mt}$ & 2.07 \\
\hline Biodiesel & & & 0.9 & Mt & 1.35 \\
\hline Total & & & & & 34.18 \\
\hline
\end{tabular}

Note: Han el al. (2016).

\section{(2) Quantity of straw resources}

China's annual theoretical maximum crop straw resource is $820 \mathrm{Mt}$ though only $690 \mathrm{Mt}$ is available for collection, mainly in 13 major grain-producing provinces on the North China Plain, the Middle-lower Yangtze River Plain, and the Northeast Plain (Han el al., 2016). Out of this, an estimated 340 Mt of crop straw are available for energy use per year. In addition, there are approximately $120 \mathrm{Mt}$ of agricultural processing residues (such as rice husks and bagasse) available each year, half of which is available for energy use (Han el al., 2016). In practice, the total amount of agricultural waste available for energy use is approximately $400 \mathrm{Mt}$ (200 Mtce), of which approximately 5\% (20 Mt or $10 \mathrm{Mtce}$ ) is currently used (Han el al., 2016). Corn straw accounts for the largest part (31.9\%) of crop straw resources in China while rice straw and wheat straw account for $27.8 \%$ and $19.5 \%$, respectively (National Statistics Bureau of China, 2016).

\section{(3) Usages of straw resources in China}

In China, about $43 \%$ of crop straw is used as fuel wood, $24 \%$ is used as fodder, $15 \%$ is burnt directly, $15 \%$ is returned to fields as fertilizer and $3 \%$ is used as industrial materials (National Renewable Energy Center of China, 2016).

\subsubsection{Production of biogas from straw in China}

As shown in Figure 1, the total cumulative and running numbers of concentrated straw biogas supply in China increased considerably between 2008 and 2013. Over the period the total cumulative number 
1 increased by $21 \%$ annually from 178 to 458 , while the running number increased by $18 \%$ from 159 to

2 368. Across the same period, the number of straw biogas gas supply households increased from 11,800 3 to 77,600 (Chen, 2014).

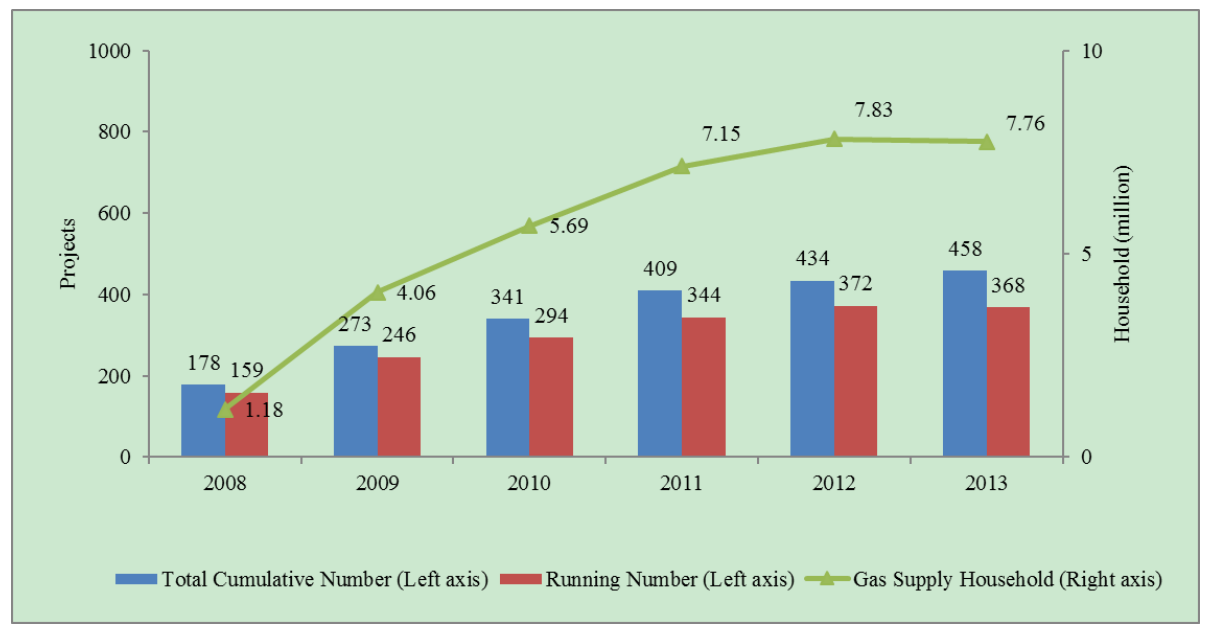

Figure 1. The total cumulative and running numbers of concentrated straw biogas supply in China (Data Source: Chen (2014))

China's straw biogas industry is currently undergoing substantial changes. Biogas projects with a daily output of tens of thousands of cubic meters can be operated commercially and have relatively mature processes governing the raw material collection, pretreatment, fermentation, and purification stages. These larger projects tend to reflect a trend towards higher efficiencies, well-organized business model and gas clean-up to boost the energy content of the biogas.

\subsection{Literature Review}

Many studies have analyzed biomass energy projects focusing on one or two aspects such as energy consumption, greenhouse gas (GHG) emissions and economic performance but not on the overall benefit (He et al., 2011; Henry, 2010; Wei et al., 2011). Energy consumption and GHG emission are very important issues for biomass energy projects, and Life Cycle Analysis (LCA) is one of the best tools to assess energy consumption and GHG emissions of different projects (Rathore et al., 2016). LCA can be done in a case by case fashion to reveal international or regional differences and there are many studies focusing on LCA of biodiesel and bioethanol technologies (Huang, 2016; Li, 2015; Rathore et al., 2016; Zhao et al., 2010; Zhong et al., 2016). LCA for renewable natural gas produced from corn straw received much less attention, especially in the context of China. Similarly, analysis on operation mode and business model is also needed to supplement the current literature on biogas projects. 
In summary, overall performance analysis on energy saving, GHG emission reduction and

2 economic efficiency for natural gas production from corn straw in China is urgently needed. The results can help inform decision making in the operation of current projects and development of future projects.

\section{1.4. Research focus and structure of this paper}

5 The aim of this paper is to assess the overall performance of actual projects producing natural gas 6 from corn straw in China with respect to energy saving, GHG emission reduction and economic 7 efficiency. The analysis includes how the production process is organized, the life-cycle energy 8 consumption and GHG emissions, and an economic analysis. Using our case study, the paper also 9 provides details of relevant policies in China to help inform other countries that are looking to develop 10 a circular economy around using crop straw to produce energy.

11 The remaining sections of the paper are arranged as follows: Section 2 introduces the background of 12 the case study, featured operational modes and assessment methodologies; Section 3 explains key data 13 and assumptions; Section 4 presents the main results and discussions; and the final section, Section 5, 14 concludes with reference to the associated policy implications.

\section{Case study background and research methods}

\subsection{Case study background}

The site chosen for the case study in this paper was a biogas project in Ar Horqin Banner, Inner Mongolia of China, where approximately RMB 300 million ( US\$ 50 million) has been invested to construct the project shown in Figure 2. The project includes systems that collect the raw materials, produce and purify the biogas, distribute the produced gas to end-users and co-producing organic fertilizer for sale. 


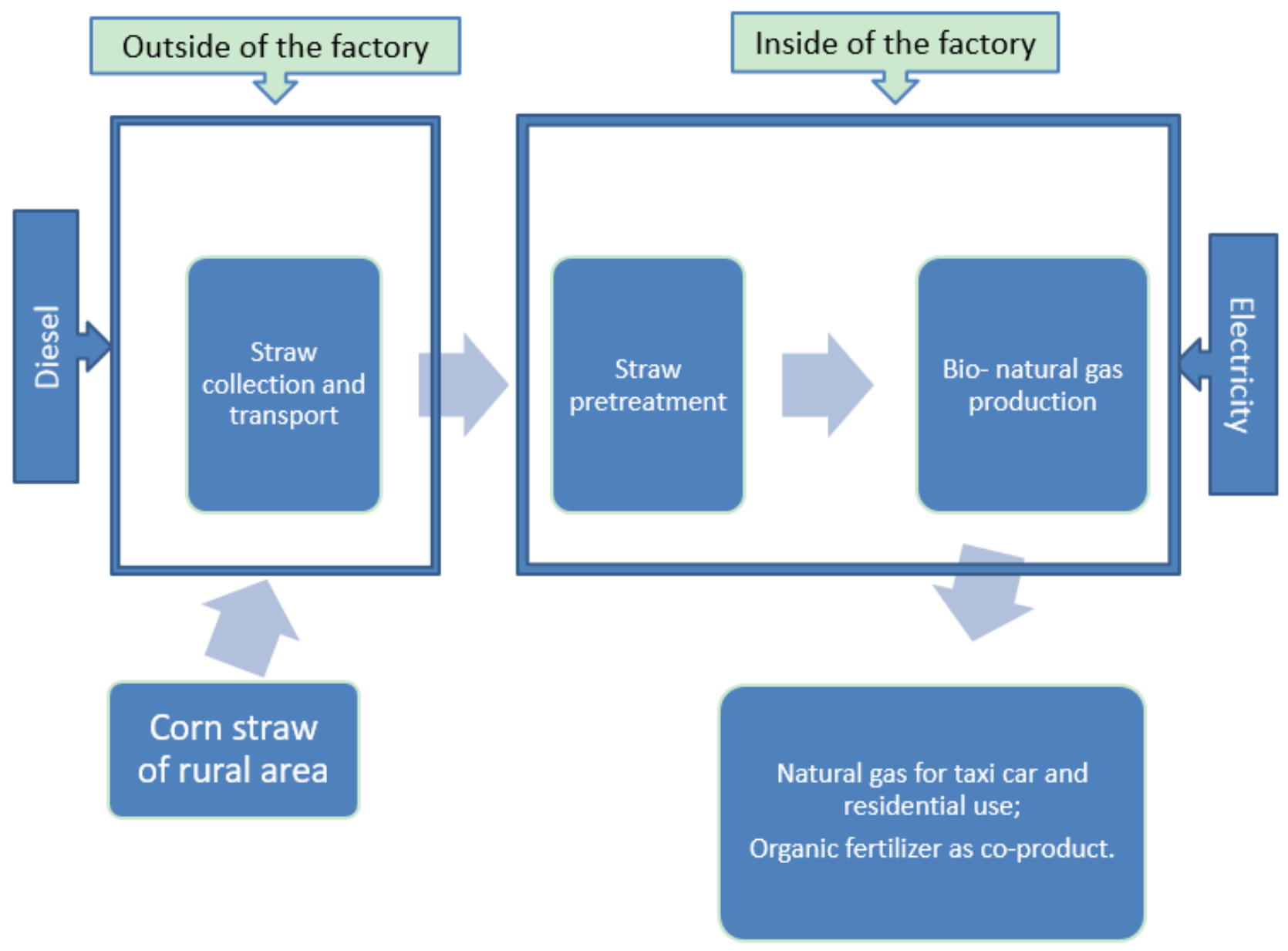

Figure 2. Overview of the processes producing natural gas from corn straw in the case study

The site includes 12 anaerobic fermentation tanks for producing biogas, each with a capacity of 5,000 cubic meters, supporting facility (for producing biogas), an organic fertilizer production line, urban automobile gas filling stations, rural cylinder depositories, and the corresponding gas transmission and distribution network. The project consumes 55,000 tonnes of corn straw annually and produces 10.8 million cubic meters of natural gas (methane), which can provide gas for about 10,000 urban households and 5,000 rural households as well as fuel for approximately 500 local taxis. The project also produces 50,000 tonnes of organic fertilizer and 29.7 tonnes carbon dioxide fertilizer as byproducts (Tsinghua University, 2016).

It is worth noting that in Ar Horqin Banner, where the case study sited, there are relatively scarce commercial energy available and weak infrastructure for natural gas import. Therefore, local decentralized energy technology is necessary.

We have conducted a field survey on the case study project and collected lots of energy use, material and labor input, products output and price data. The acquired data from the field survey will be used to 
assess this project, combined with data from other sources such as the literature, as mentioned in Section 3.1 .

\subsection{Specific featured business models in this project}

The raw materials for the studied project are mainly sourced and stored by the project company itself, though a portion is also acquired through brokers. There are three distinct business models used in sourcing the biomass materials: "Nongbaomu" (contracted agricultural management), "Nengbaomu" (contracted energy management) and "Mutual Offsetting in Kind" (product replacement). It is recognized that the studied project benefited from these featured business models based on our on-site survey.

In the Nongbaomu model the project provides equipment to the agricultural producers and oversees the agricultural inputs and services (such as soil preparation, sowing, and harvesting) with the farmers ultimately owning the grains once the project recovers its costs.

The Nengbaomu model operates by supporting biogas and organic fertilizer production plants in areas close to large-scale livestock and poultry enterprises, or by signing contracts for sewage treatment.

The product replacement model replaces the raw materials (straw or manure) with the biogas and organic fertilizer products, and promotes the Nongbaomu mode through the construction of energy distribution stations and gas pipeline networks. This kind of mutual offsetting in kind business model allows farmers who sell straw to the project to buy a quota of the project's natural gas products at subsidized prices.

\subsection{Methods for energy consumption and GHG emission analysis}

\subsubsection{System boundaries, functional unit, and comparative pathway design}

The paper uses Life Cycle Analysis (LCA) to analyze this case of corn straw-based bio-natural gas (BNG) production process. In the system boundary shown in Figure 3, energy inputs include diesel fuel in the transport phase and electricity in the production phase. The outputs include BNG for domestic and vehicle customers and the fertilizer byproduct. This corn straw-based BNG pathway will be analyzed in depth in this study to assess the overall energy saving and GHG emission reductions. Life-cycle fossil primary energy (coal, petroleum and natural gas) and GHG (including $\mathrm{CO}_{2}, \mathrm{CH}_{4}$ and $\mathrm{N}_{2} \mathrm{O}$ ) emissions can be investigated using LCA (covering both the upstream and use stages) on the diesel and electricity. 


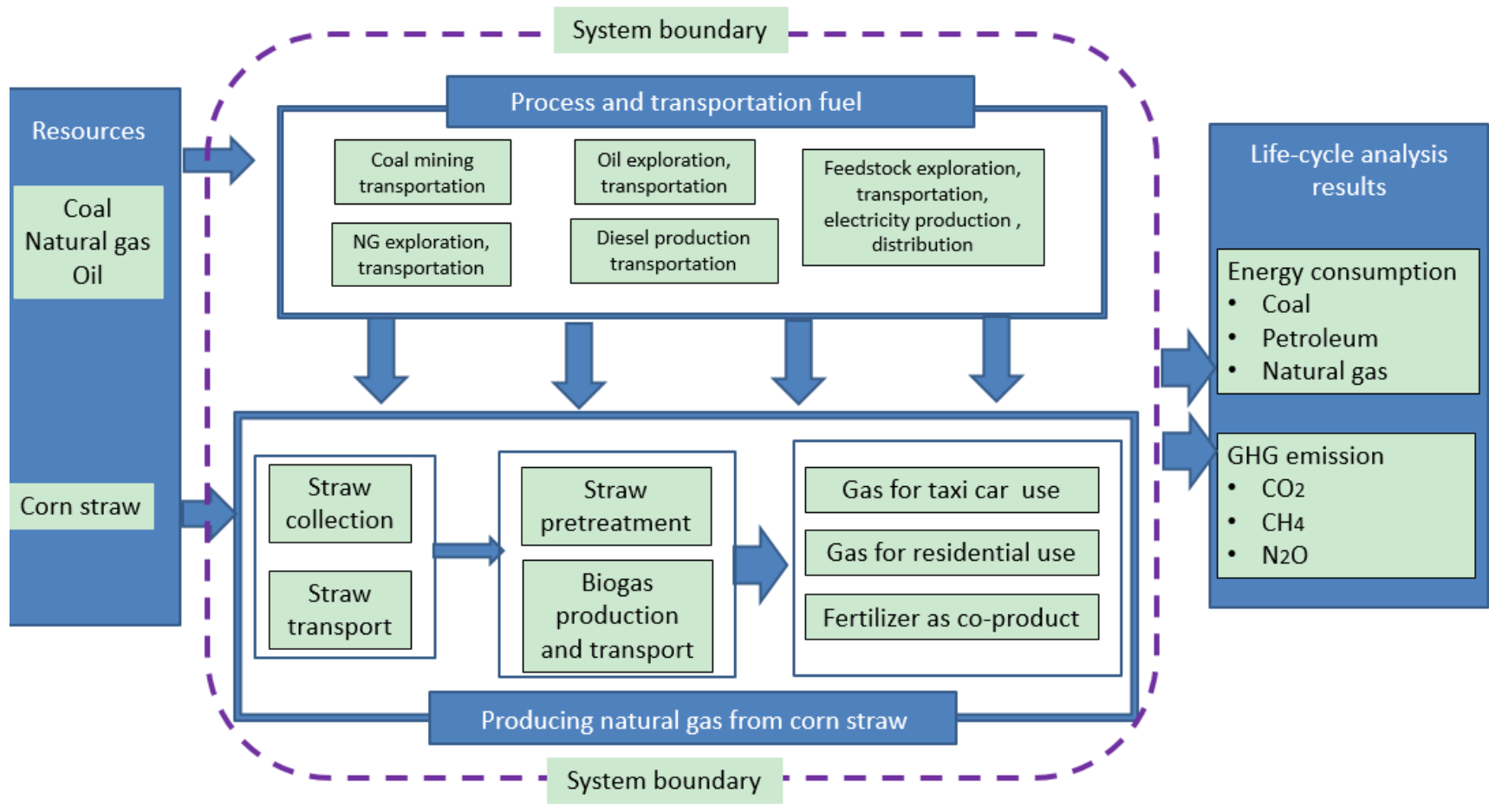

Figure 3. The system boundary of the LCA for the case study of producing BNG from corn straw

The functional unit is a compound unit, which include energy and fertilizer services provided by BNG and organic fertilizer in a year from the aforementioned system.

We have used three pathways for the comparison. The baseline (BSL) pathway is used as a reference to assess the energy saving and GHG emission reductions of the BNG pathway. It is assumed that in the BSL pathway non-vehicle energy services are provided by fossil natural gas, vehicle energy services by gasoline, and fertilizer services by conventional fertilizers. Another pathway investigated is the Contrasting Pathway 2 (CP2), which is similar to BSL except for the assumption that vehicle energy services are provided by fossil natural gas. The system boundaries for the LCA of the comparative pathways are similar to that of the BNG pathway. We will study the life-cycle fossil primary energy and GHG emissions by considering the upstream stages of the energy production and fertilizer production for the end-use energy demand and conventional fertilizer in the functional unit.

\subsubsection{Calculation methods}

\section{(1) Key variables related to life-cycle stages and pathways}

The key variables related to life-cycle stages and pathways are listed in Table 4 and will be used in the calculations of life-cycle fossil primary energy and GHG emissions.

Table 4. The interpretation of i, j, k, land $\mathrm{m}$

Name Definitions




\begin{tabular}{cc}
\hline & Process i for BNG pathway \\
\hline 1 & Straw collection and transportation \\
2 & Straw pretreatment and biogas production \\
\hline & Comparative pathway $\mathbf{j}$ \\
\hline 1 & BSL \\
2 & CP2 \\
\hline & Energy input/demand $\mathbf{~}$ \\
\hline 1 & Diesel \\
2 & Electricity \\
3 & Natural gas \\
4 & Gasoline \\
5 & Coal \\
\hline & Energy service demand $\mathbf{~}$ \\
\hline 1 & Residential consumption \\
2 & Vehicle use (taxi) \\
\hline & Fossil primary energy $\mathbf{m}$ \\
\hline 1 & Coal \\
3 & Natural gas \\
\hline
\end{tabular}

\section{(2) End-use energy input for BNG pathway}

As shown in Equation (1) for the BNG pathway, the total energy input required to produce the output energy services and fertilizer $\left(E_{B N G, k}\right)$ is the sum of the product of the activity $Y_{i, B N G}$ of process $\mathrm{i}$ and the activity energy conversion factor of process $\mathrm{i}$ for a given input $\mathrm{k}\left(C_{i, B N G, k}\right)$.

$$
E_{B N G, k}=\sum_{i} Y_{i, B N G} \times C_{i, B N G, k}
$$

\section{(2) End-use energy demand for comparative pathways}

For the comparative pathways, $E_{j, k}$ is the amounts of end-use energy type $\mathrm{k}$ for pathway $\mathrm{j}$, and can be calculated by Equation (2). $Y_{l, j, k}$ is the energy service demand $\mathrm{l}$ for end-use energy type $\mathrm{k}$ for pathway j, $F E$ is the demand for the fertilizer service, and $C_{k}$ is the k kind of energy needed per unit of fertilizer service.

$$
E_{j, k}=\sum_{l} Y_{l, j, k}+F E * C_{k}
$$

\section{(3) Life-cycle fossil energy consumption and GHG emissions}

Life-cycle fossil primary energy consumption for pathway $\mathrm{j}\left(\mathrm{LPEC}_{j}\right)$ is calculated based on end-use energy input/demand $\left(E_{j, k}\right)$ and the life-cycle energy coefficient $\left(a_{m, k}\right)$ as in Equation (3):

$$
\mathrm{LPEC}_{j}=\Sigma_{m, k}\left(E_{j, k} * a_{m, k}\right)
$$


Life-cycle GHG emissions associated with the energy consumption $\mathrm{GHG}_{j}$ were calculated using the corresponding lifecycle emissions coefficient $\left(b_{k}\right)$ by Equation (4).

$$
\mathrm{GHG}_{j}=E_{j, k} * b_{k}
$$

\section{(4) Energy saving and GHG emissions reduction rates}

The energy saving rate for the BNG pathway compared to those in pathway $\mathrm{j}\left(\mathrm{ESR}_{j}\right)$ is calculated using Equation (5).

$$
\mathrm{ESR}_{j}=1-L P E C_{B N G} / L P E C_{j}
$$

The GHG emissions reduction rate for the BNG pathway compared to those in pathway $\mathrm{j}\left(\mathrm{GRR}_{j}\right)$ is calculated using Equation (6).

$$
\mathrm{GRR}_{j}=1-G H G_{B N G} / G H G_{j}
$$

\section{(5) Economic analysis}

The net present value (NPV) analysis is used in our study. As shown in Equation (7), the NPV for a given year in the future $(t)$, is calculated using the net cash flow $\left(\mathrm{CF}_{\mathrm{t}}\right)$ of year $\mathrm{t}$ (including non-cash expenses such as depreciation and amortization) and the discount rate $\mathrm{r}$. When NPV is set to 0 , we can get the value of $r$ as the internal rate of return (IRR) of this project. IRR and payback period are the main economic indicators used to evaluate the economic performance.

$$
\mathrm{NPV}=\sum_{\mathrm{t}} \mathrm{CF}_{\mathrm{t}} /(1+\mathrm{r})^{\mathrm{t}}
$$

Here we calculate $\mathrm{CF}_{\mathrm{t}}$ and net income (NI) in year $\mathrm{t}$ by Equations (8) and (9), respectively. FA is fixed asset value and Year is the period for depreciation; AS is annualized subsidies; $P_{\mathrm{CO}_{2}}, P_{\text {gas }}, P_{\text {fertilizer }}$ are prices of carbon dioxide fertilizer, commercial natural gas and organic fertilizer; $Q_{\mathrm{CO}_{2}}, Q_{\text {gas }}, Q_{\text {fertilizer }}$ are sales of carbon dioxide fertilizer, commercial natural gas and organic fertilizer; $\mathrm{C}_{\text {straw }}$ is cost of straw including transportation charges; $\mathrm{W}$ is wage; $\mathrm{C}_{\text {other }}$ denotes other cost including operation and management cost; and $\mathrm{R}_{\operatorname{tax}}$ is the tax rate.

$$
\mathrm{CF}_{\mathrm{t}}=\mathrm{NI}+\mathrm{FA} / \text { Year }-\mathrm{AS}
$$

$$
\begin{gathered}
\mathrm{NI}=\left(P_{\mathrm{CO}_{2}} * Q_{\mathrm{CO}_{2}}+P_{\text {gas }} * Q_{\text {gas }}+P_{\text {fertilizer }} * Q_{\text {feitilizer }}-\mathrm{C}_{\text {straw }}-\mathrm{FA} / \text { Year }-\mathrm{W}-P_{\text {elec }} * Y_{2 B N G} *\right. \\
\left.C_{2 B N G 2}-\mathrm{C}_{\text {other }}+\mathrm{AS}\right) *\left(1-\mathrm{R}_{\text {tax }}\right)
\end{gathered}
$$


In Table 5 to 8, we list the key data and assumptions for the life cycle energy and GHG analysis. Most of these are taken from the literature (Ji et al., 2012; Liu et al., 2011; Luo et al., 2007; Ou et al., 2013; Yue et al., 2006; Zhao et al., 2010) and the rest is based on our on-site survey. For example, we surveyed the project staff to get a rough estimate of electricity use by estimating the running time and capacity of the equipment. What's more, the life cycle fossil energy factors and GHG factors used in the 7 studied project are both taken from our previous studies (Ou et al., 2013).

Table 5. Output-related data in the studied project

\begin{tabular}{|c|c|c|c|c|}
\hline $\begin{array}{c}\text { Variable/ } \\
\text { Coefficient }\end{array}$ & Notes & Value & Unit & $\begin{array}{r}\text { Source } \\
\text { and note }\end{array}$ \\
\hline$Y_{1, B N G}$ & Total mileage of taxis & 15.7 & Million km & $\begin{array}{l}\text { On-site } \\
\text { survey }\end{array}$ \\
\hline$Y_{2, B N G}$ & $\begin{array}{l}\text { Running time of electrical equipment in } \\
\text { the production process }\end{array}$ & 8760 & Hours & $\begin{array}{l}\text { On-site } \\
\text { survey }\end{array}$ \\
\hline$Y_{1,1,3}$ & $\begin{array}{l}\text { Natural gas needed by residents under the } \\
\text { BSL pathway }\end{array}$ & 2.715 & $\begin{array}{l}\text { Million cubic } \\
\text { meters }\end{array}$ & $\begin{array}{l}\text { On-site } \\
\text { survey }\end{array}$ \\
\hline$Y_{1,2,3}$ & $\begin{array}{l}\text { Natural gas needed by residents under the } \\
\text { BSL pathway }\end{array}$ & 2.715 & $\begin{array}{l}\text { Million cubic } \\
\text { meters }\end{array}$ & $\begin{array}{l}\text { On-site } \\
\text { survey }\end{array}$ \\
\hline$Y_{2,1,4}$ & $\begin{array}{c}\text { Gasoline required by taxis in Contrasting } \\
\text { Pathway } 1\end{array}$ & 210 & Million L & $\begin{array}{l}\text { On-site } \\
\text { survey }\end{array}$ \\
\hline$Y_{2,2,3}$ & $\begin{array}{c}\text { Gas required by taxis in Contrasting } \\
\text { Pathway } 2\end{array}$ & 8.085 & $\begin{array}{l}\text { Million cubic } \\
\text { meters }\end{array}$ & $\begin{array}{l}\text { Luo et al., } \\
\quad 2007\end{array}$ \\
\hline$F E$ & $\begin{array}{l}\text { Demand for fertilizer under the BSL } \\
\text { pathway }\end{array}$ & 5.3 & $\begin{array}{l}\text { Thousand } \\
\text { tonnes }\end{array}$ & Ji et al., 2012 \\
\hline
\end{tabular}

Table 6. Conversion factors data used in the studied project

\begin{tabular}{|c|c|c|c|c|}
\hline $\begin{array}{r}\text { Variable/ } \\
\text { Coefficient }\end{array}$ & Notes & Value & Unit & Source and note \\
\hline$C_{1, B N G, 1}$ & $\begin{array}{c}\text { Diesel fuel } \\
\text { consumption per km }\end{array}$ & 7 & $\mathrm{~L} / 100 \mathrm{~km}$ & Luo et al., 2007 \\
\hline$C_{2, B N G, 2}$ & $\begin{array}{l}\text { Factory electricity } \\
\text { capacity factor }\end{array}$ & 960 & $\mathrm{kWh}$ & On-site survey \\
\hline$C_{1}$ & $\begin{array}{l}\text { Diesel required per } \\
\text { tonne of fertilizer }\end{array}$ & 26 & $\mathrm{~L}$ & Ji et al., 2012 \\
\hline$C_{2}$ & $\begin{array}{l}\text { Electricity required } \\
\text { per tonne of fertilizer }\end{array}$ & 41.7 & $\mathrm{kWh}$ & Ji C L., et al., 2012 \\
\hline$C_{5}$ & $\begin{array}{l}\text { Coal required per } \\
\text { tonne of fertilizer }\end{array}$ & 19.7 & $\mathrm{~kg}$ & Ji C L., et al., 2012 \\
\hline
\end{tabular}

Table 7. Life cycle energy coefficients used in the studied project [36].

\begin{tabular}{|c|c|c|c|c|}
\hline \multirow{2}{*}{ Item } & \multirow{2}{*}{ Life-cycle energy coefficient } & \multicolumn{3}{|c|}{ By type of primary energy } \\
\hline & & Coal & Gas & Petroleum \\
\hline Units & \multicolumn{4}{|c|}{$\mathrm{MJ} / \mathrm{MJ}$} \\
\hline Coal & 1.172 & 1.061 & 0.001 & 0.110 \\
\hline Natural gas & 1.196 & 0.081 & 1.015 & 0.065 \\
\hline Diesel & 1.319 & 0.156 & 0.027 & 1.119 \\
\hline Gasoline & 1.331 & 0.164 & 0.049 & 1.130 \\
\hline Electricity & 2.924 & 2.572 & 0.021 & 0.330 \\
\hline
\end{tabular}


Table 8. Life cycle GHG factors used in the studied project

\begin{tabular}{|c|c|c|c|c|}
\hline $\begin{array}{c}\text { Variable/ } \\
\text { Coefficient }\end{array}$ & Notes & Value & Unit & Source and note \\
\hline$b_{1}$ & $\begin{array}{l}\text { Full life cycle GHG } \\
\text { emission of diesel fuel }\end{array}$ & 102.4 & $\mathbf{g C O}_{2, \mathrm{e}} / \mathbf{M J}$ & Ou et al., 2013 \\
\hline$b_{2}$ & $\begin{array}{l}\text { Full life cycle GHG } \\
\text { emission of electricity }\end{array}$ & 289.6 & $\mathrm{gCO}_{2, \mathrm{e}} / \mathrm{MJ}$ & Ou et al., 2013 \\
\hline$b_{3}$ & $\begin{array}{c}\text { Full life cycle GHG } \\
\text { emission of natural } \\
\text { gas }\end{array}$ & 72.73 & $\mathrm{gCO}_{2, \mathrm{e}} / \mathbf{M J}$ & Ou et al., 2013 \\
\hline$b_{4}$ & $\begin{array}{l}\text { Full life cycle GHG } \\
\text { emission of gasoline }\end{array}$ & 98.86 & $\mathrm{gCO}_{2, \mathrm{e}} / \mathrm{MJ}$ & Ou et al., 2013 \\
\hline$b_{5}$ & $\begin{array}{l}\text { Full life cycle GHG } \\
\text { emission of coal }\end{array}$ & 104.5 & $\mathrm{gCO}_{2, \mathrm{e}} / \mathrm{MJ}$ & Ou et al., 2013 \\
\hline
\end{tabular}

\begin{tabular}{cccc}
\hline Variable/ Coefficient & Value & Unit & Source and note \\
\hline FA & 44.1 & Million USD & On-site survey \\
Year & 10 & Years & Assumption \\
$\mathrm{AS}$ & 0.1 & Million USD & On-site survey \\
$P_{\mathrm{CO}_{2}}$ & 29.4 & USD/Tonne & On-site survey \\
$Q_{\mathrm{CO}_{2}}$ & 29.7 & Tonne & On-site survey \\
$P_{\text {gas }}$ & 0.56 & USD/cubic meter & On-site survey \\
$Q_{\text {gas }}$ & 10.8 & Million cubic meter & On-site survey \\
$P_{\text {fertilizer }}$ & 147 & USD/Tonne & On-site survey \\
$Q_{\text {feitilizer }}$ & 50 & Thousand Tonnes & On-site survey \\
$\mathrm{C}_{\text {straw }}$ & 1.6 & Million USD & On-site survey \\
$\mathrm{W}_{\text {elec }}$ & 0.3 & Million USD & On-site survey ${ }^{2}$ \\
$\mathrm{C}_{\text {other }}$ & 0.07 & USD/kWh & On-site survey ${ }^{3}$ \\
$\mathrm{R}_{\text {tax }}$ & 2.9 & Million USD & On-site survey \\
& $25 \%$ & - & On-site survey \\
\hline
\end{tabular}

\subsection{Data for economic analysis}

In Table 9, we list the key data and assumptions for the economic analysis. The gas price was RMB 3.8/L (about US\$ 0.56/L) based on price information observed at the gas filing stations and surveying the residents. The price for carbon dioxide gas fertilizer was RMB 180/tonne ( US\$ 26.47/tonne) and the price for organic fertilizer was RMB 1,000/tonne ( US\$ 147/tonne). The equipment amortization period was 10 years and the income tax rate was $25 \%$. For wage expenditure, each of the two gas stations was assumed to employ 10 people at an average annual wage of RMB 110,000 ( US\$ 16,176.47). For electricity, we assumed that the total capacity was $1,280 \mathrm{~kW}$ and that annual consumption was about 8.4 million kWh. Other costs of RMB 30 million ( US\$ 4.41 million) per year were also assumed.

(1)

\section{Table 9. Key data related to economic data used in the studied project}




\section{Results and discussions}

\subsection{Results of lifecycle primary fossil energy use and GHG emissions}

4

9

Table 10. Life-cycle primary energy consumption and GHG emissions in different pathways

\begin{tabular}{lcccc}
\hline Pathway & Unit & BNG & BSL & CP2 \\
\hline Total energy & $10^{6} \mathrm{MJ}$ & 141.2 & 7489.2 & 751.6 \\
Raw coal & $10^{6} \mathrm{MJ}$ & 84.2 & 1131.2 & 290.2 \\
Crude oil & $10^{6} \mathrm{MJ}$ & 55.3 & 5996.6 & 52.8 \\
Natural gas & $10^{6} \mathrm{MJ}$ & 1.7 & 361.4 & 408.5 \\
GHG & $10^{3}$ ton & 13.1 & 771.0 & 290.1 \\
\hline
\end{tabular}

The breakdown of GHG emission of the BNG pathway is shown in Figure 4. We can see that upstream emissions of electricity used in the project dominates the life-cycle emissions (about 70\%) while the emission during the straw transportation stage ranks the second (about 30\%). The other stages are insignificant for the total GHG emissions. The results of annual lifecycle primary fossil energy use and GHG emissions in different pathways are shown in Table 10. We can see that the total lifecycle primary fossil energy saving in the BNG pathway is about $98 \%$ and $80 \%$ compared with the BSL and CP2 pathways, respectively.

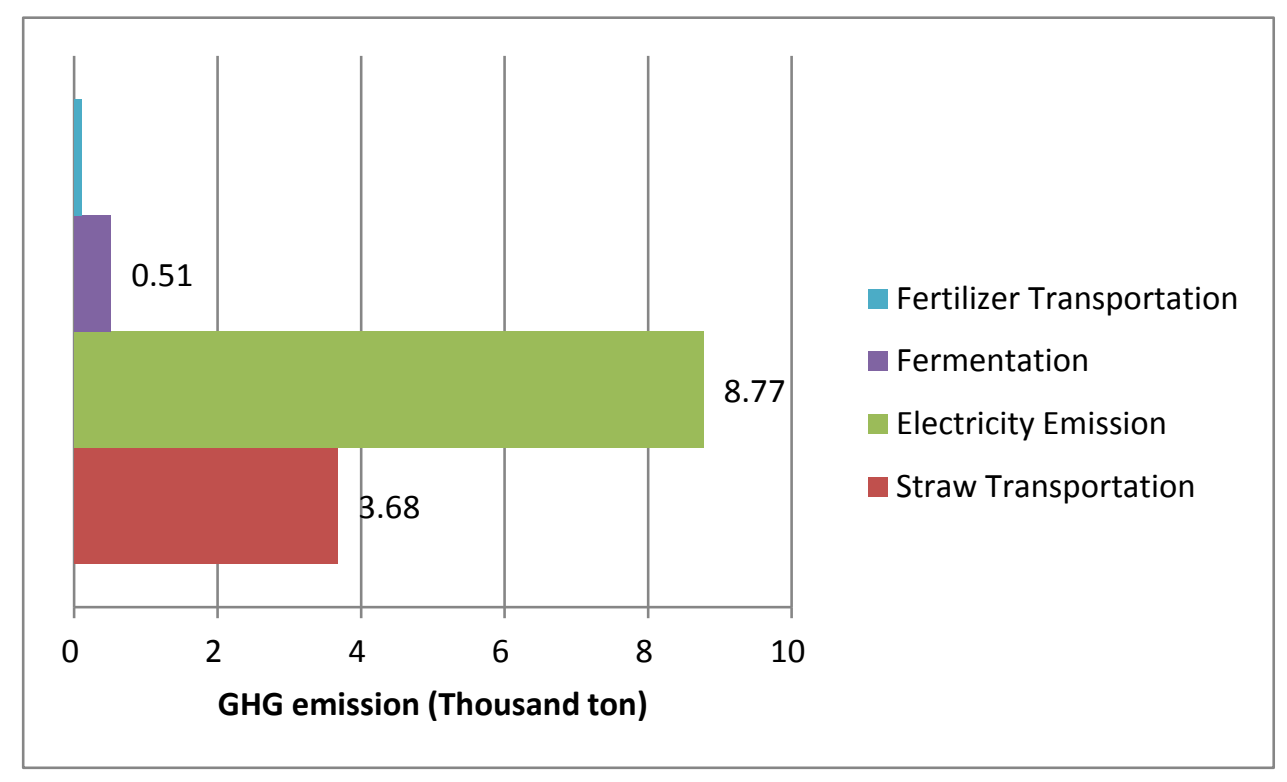



those from the fossil-fueled pathways.

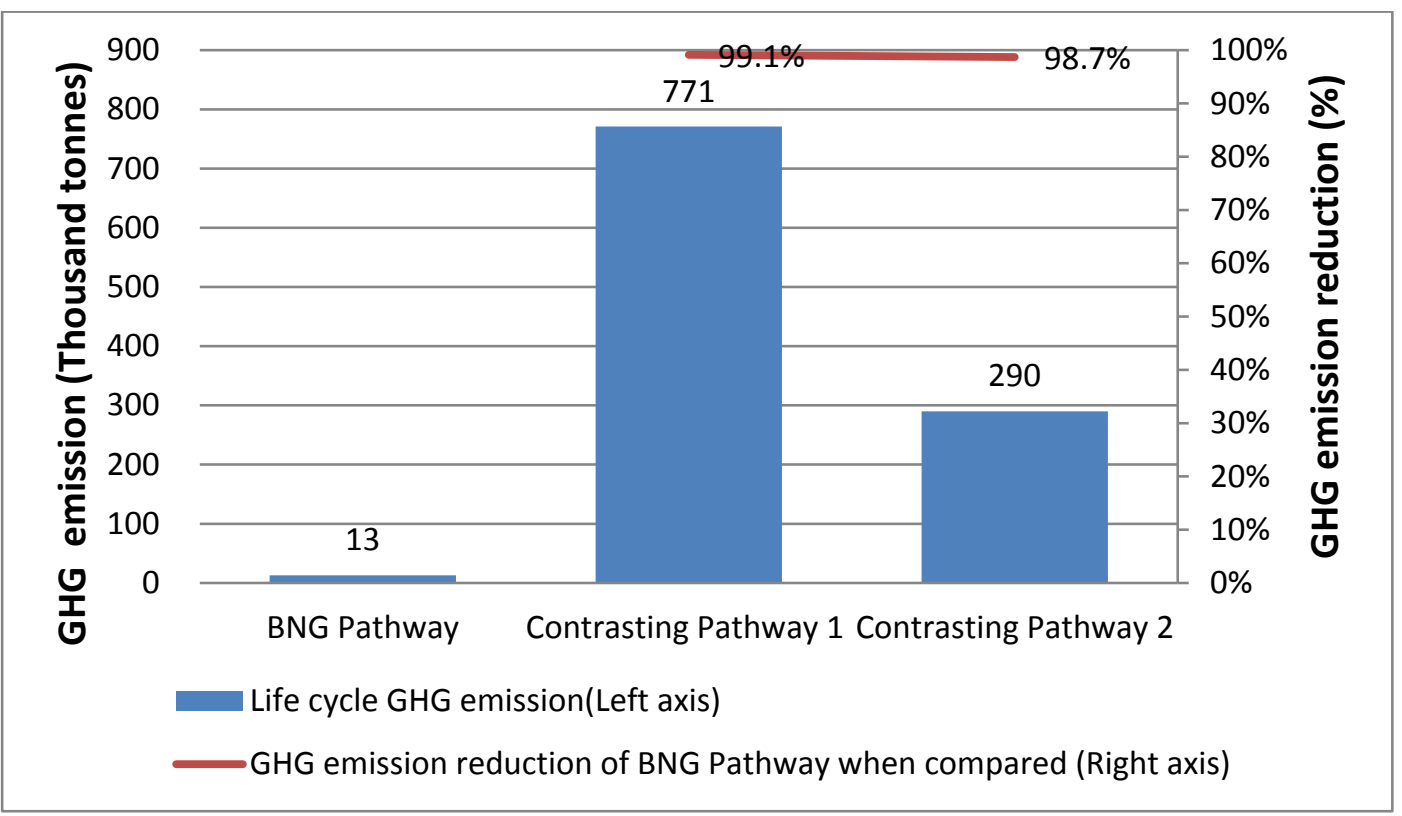

Figure 5. Life-cycle GHG emissions for the various pathways

6

7

8

Figure 6 shows the GHG emissions attributed to the various end-uses of the products for the comparative fossil-fueled pathways. Emissions from vehicle use dominated when gasoline was used to drive taxis in BSL/Contrasting Pathway 1 (68\%). This percentage reduced significantly by switching 9 from gasoline to natural gas in Contrasting Pathway $2(11 \%)$.

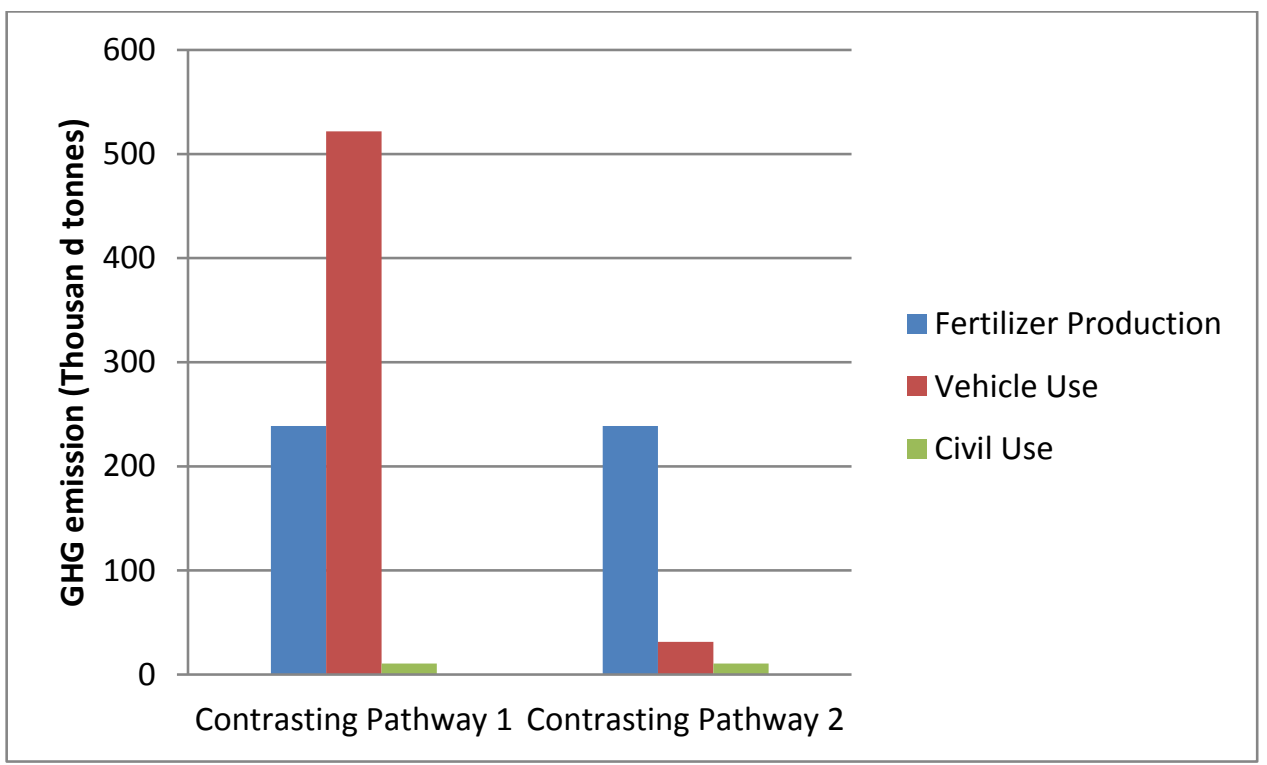


Table 10. Research results comparison of energy saving and GHG emission reduction

\begin{tabular}{|c|c|c|c|c|c|}
\hline Sources & Region & $\begin{array}{l}\text { Researched } \\
\text { System }\end{array}$ & $\begin{array}{l}\text { Compared/ } \\
\text { Reference } \\
\text { system }\end{array}$ & $\begin{array}{l}\text { Energy saving } \\
\text { effect }\end{array}$ & $\begin{array}{l}\text { GHG } \\
\text { emissions } \\
\text { reduction } \\
\text { effect }\end{array}$ \\
\hline & China & Corn BNG & Fossil fuel & $98.2 \%$ & $99.1 \%$ \\
\hline This study & China & Corn BNG & Fossil fuel & $81.2 \%$ & $98.7 \%$ \\
\hline $\begin{array}{l}\text { Zhang et } \\
\text { al., } 2009\end{array}$ & China & $\begin{array}{l}\text { BNG (kitchen, } \\
\text { toilet and pigpen) }\end{array}$ & Coal & & $88.63 \%$ \\
\hline $\begin{array}{l}\text { Zhao et al., } \\
2010\end{array}$ & China & Corn BNG & $\begin{array}{l}\text { Natural gas and } \\
\text { fertilizer }\end{array}$ & $87 \%$ & \\
\hline $\begin{array}{l}\text { Zhang et al., } \\
2013\end{array}$ & China & $\begin{array}{l}\text { Bioethanol } \\
\text { (cassava, sugar } \\
\text { grass and corn) }\end{array}$ & Fossil fuel & $-60 \%$ to $60 \%$ & \\
\hline $\begin{array}{l}\text { Dressler et } \\
\text { al., } 2012\end{array}$ & Germany & Corn & Fossil fuel & & $\begin{array}{l}0.058 \text { to } 0.179 \\
\mathrm{~kg} \mathrm{CO}_{2} \mathrm{eq} / \mathrm{kWh}\end{array}$ \\
\hline $\begin{array}{l}\text { Korres et al., } \\
2010\end{array}$ & Ireland & Grass & Fossil diesel & Positive & $54 \%$ to $75 \%$ \\
\hline $\begin{array}{l}\text { Ottmar, } \\
2011\end{array}$ & Global & BNG & Fossil fuel & & About $60 \%$ \\
\hline
\end{tabular}

\subsection{Economic analysis results}

It is found that the project needs about 7 years to recover its initial costs (without the one-time subsidy). Over a 10-year period, the project's IRR would be $4.3 \%$ with the annualized subsidy. Our analysis indicates that this kind of projects still need policy support from the government. A period of 15 years yielded an IRR of $10 \%$, suggesting that policy incentives are still required.

\subsection{Research results comparison of energy saving and GHG emission reduction}

As Table 10 shows, similar studies on the energy saving and emission reduction effects of BNG produce varying results, possibly due to the different role of byproducts (i.e. fertilizer) in these studies (Rathore, 2016; Zhang et al., 2013). In our case studied, the pathway producing BNG from corn straw has higher energy saving and GHG emissions reduction effects than most other studies (Dressler et al., 2012; Korres et al., 2010; Zhang et al., 2013; Zhang et al., 2009; Zhao et al., 2010) and an estimate of the world average level (Ottmar, 2011). 
Figure 7. Sensitivity of life cycle GHG emissions in the BNG pathway to fertilizer production

\subsubsection{Economic analysis}

Figure 8 shows that both a production capacity subsidy and an end product subsidy can improve the viability of the project. However, both may also have negative impacts with subsidies. The product subsidy can potentially cause arbitrary effects where traditional energy replacing cleaner sources while subsidies based on production capacity may not encourage efficient production.

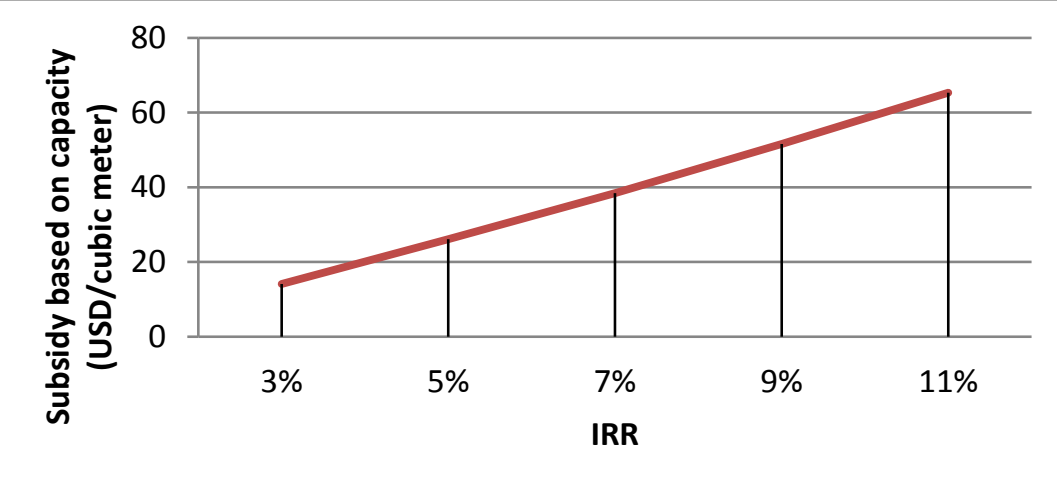

Figure 8. Viability analysis for different levels of capacity subsidy

\section{Concluding remarks}


Globally, crop straw is a rich resource and the further establishment of its use as an energy source is an important aspect in developing the circular economy. Projects in this vein can bring benefits such as improving access to energy and living conditions as well as boosting the local economy and employment opportunities in rural communities. For efficient distribution of produced BNG, the existing natural gas networks can be utilized with end applications in electricity, thermal, and transportation energy generation.

Through a detailed case study of the production of BNG from corn straw in China, we find that using the "Nongbaomu" business model (whereby professional personnel assist farmers in the management of straw collection, bundling, storage and transportation) and the "Mutual Offsetting in Kind" business model (whereby farmers can buy a quota of the project's BNG products at a lower price in return for selling straw to the project) can ensure the acquisition of straw by the BNG project at stable prices and high quality.

Because the main product (BNG purified from biogas) replaces refined oil products used by automobiles and the byproduct (organic fertilizer) replaces traditional fertilizer (produced using coal), the project offers the potential for significant decreases (more than 80\%) in life cycle GHG emissions and fossil fuel use. Benefited from the relatively high natural gas prices in the project location and applicable government subsidies, our studied case was found to be economically viable. However, the withdrawal of subsidies can decrease the project's net profit by half, highlighting how important policy support is to the project's continued operation. The project's internal rate of return over a 10-year period was $4.3 \%$, further indicating the need for a certain degree of policy support, though the type of this support is an area that needs further work. It can be seen that subsidies improve NPV and IRR of the project significantly.

These results are also likely to have relevance in other countries. We found that enterprises are responsible for selecting an effective business models and the most appropriate technological pathway and that governments should identify the ways in which they can support businesses to make these choices (including incentivizing them with subsidies, but also through capacity building, skills training and technology transfer).

Further, to drive a circular economy that promotes the use of crop straw for energy production governments should develop industrial policies that support the development of rural distributed energy, and introduce and implement appropriate subsidies to allow BNG to compete in the traditional natural gas market. Similarly, the government should work to develop quality standards and associated infrastructure (such as grid connections and rural gas-filling stations) to ensure the continued 
1 development of BNG and its growing contribution to rural energy development and improvement in

2 energy access.

3 Acknowledgements

4 This project was co-sponsored by key project of the China National Social Science Foundation

5 (16AGL002) and the National Natural Science Foundation of China (71690240, 71373142 and $671673165)$.

\section{References}

[1] ARENA, 2015. ARENA Annual Report 2015.

[2] Cardoen, D., Joshi, P., Diels, L., Sarma, P. M., \& Pant, D, 2015. Agriculture biomass in India: Part 1. Estimation and characterization. Resources Conservation and Recycling, 39-48.

[3] Cardoen, D., Joshi, P., Diels, L., Sarma, P. M., \& Pant, D, 2015. Agriculture biomass in India: Part 2. Post-harvest losses, cost and environmental impacts. Resources Conservation and Recycling, 143-153.

[4] Chen X H, 2014. China Agriculture Statistical Report. China Agriculture Press, Beijing. (In Chinese)

[5] Dressler, D., Loewen, A., Nelles, M., 2012. Life cycle assessment of the supply and use of bioenergy: impact of regional factors on biogas production. Int. J. Life Cycle Assess. 17, 1104-1115.

[6] Fernandez E, Saini R P, Devadas V, 2005. Relative inequality in energy resource consumption: a case of Kanvashram village, Pauri Garhwal district, Uttranchall (India). Renewable Energy, 30(5):763-772.

[7] Gao Z Q.; Zhao J T.; Sun Z J; Fan H.; Li X Y, 2014. Research on Typical Power Supply Modes of Microgrids in Rural Power Systems. Electrical Engineering, (6):56-62.

[8] Gerardi M H, 2003. The Microbiology of Anaerobic Digesters. Wiley-Interscience, A John Wiley \& Sons.

[9] Guo S, 2014. Influence of Straw Combustion on Smog in Northern China and Its Solutions. Farm Economic Management, (3):62-63.

[10]Han W K.; Yang Y F, 2016. China Energy Outlook 2030. China Economic Press, Beijing. (In Chinese) 
[11]He, J., \& Zhang, W, 2011. Techno-economic evaluation of thermo-chemical biomass-to-ethanol. Applied Energy, 88(4), 1224-1232.

[12]Henry, R. J. ,2010. Evaluation of plant biomass resources available for replacement of fossil oil. Plant Biotechnology Journal, 8(3), 288-293.

[13] Hiremath R B, Shikha S, Ravindranath N H, 2007. Decentralized energy planning; modeling and application—a review. Renewable \& Sustainable Energy Reviews, 11(5):729-752.

[14]Huang X, 2016. Cost-Volume-Profit Analysis and Financial Evaluation on Straw Biogas Project for Central Gas Supply. China Biogas, 34(4):60-66.

[15]Ji C L.; Ding M.; Wang B X.; Wang C M.; Zhao Y W, 2012. Comparative Evaluation of Chemical and Organic Fertilizer on the Base of Life Cycle Analysis Methods. Chinese Journal of Soil Sciences, (2):412-417.

[16]Korres, N. E., Singh, A., Nizami, A. S., \& Murphy, J. D. , 2010. Is grass biomethane a sustainable transport biofuel? Biofuels Bioproducts \& Biorefining, 4(3), 310-325.

[17]Kumar A, Bhattacharya S C, Pham H L, 2003. Greenhouse gas mitigation potential of biomass energy technologies in Vietnam using the long range energy alternative planning system model. Energy, 28(7):627-654.

[18]Li X, 2015. Empirical Analysis and Optimization Research of Biogas Centralized Gas Supply. China Agriculture University. China Agriculture University Press, Beijing. (In Chinese)

[19]Liu H C.; Yin X L.; Wu C Z, 2011. Life Cycle Analysis of Energy Consumption and Greenhouse Gas Emissions of Biomass Gasification and Power Generation Systems. New Energy and Renewable Energy Graduate Seminar 2011. (In Chinese)

[20]Lu M, Chen Z, 2004. Urbanization, urban-biased economic policies and urban-rural inequality. Economic Research Journal.

[21]Luo D X.; Zheng S F, 2007. Economic Analysis of Natural Gas Vehicle. GAS \& HEAT, 27(3):2124.

[22] Munshi K, Rosenzweig M, 2015. Networks and Misallocation: Insurance, Migration, and the RuralUrban Wage Gap. American Economic Review, 106(1): 46-98.

[23] National Renewable Energy Center of China, 2016. China Renewable Energy Development Report 2015. China Environment Press, Beijing. (In Chinese) 
[24]National Statistics Bureau of China, 2016. China Statistics Annual Report 2015. China Statistics Press, Beijing. (In Chinese)

[25]NDRC, 2016. Renewable Energy Development Plan 2016-2020. http://www.ndrc.gov.cn/zcfb/zcfbtz/201612/t20161216_830264.html (Accessed 2017/07/04) (In Chinese)

[26]Nordlander, E., Holgersson, J., Thorin, E., Thomassen, M., \& Yan, J., 2012. Energy efficiency evaluation of two biogas plants. Environmental Engineering.

[27]Ottmar, E., 2011. The IPCC Special Report on Renewable Energy Sources and Climate Change Mitigation.

[28]Ou X M, Yan X Y, Xu Z, et al, 2013. Life-Cycle Energy Use and Greenhouse Gas Emissions Analysis for Bio-Liquid Jet Fuel from Open Pond-Based Micro-Algae under China Conditions. Energies, 6(9):4897-4923.

[29]Pohl M, Mumme J, Heeg K, et al., 2012.Thermo- and mesophilic anaerobic digestion of wheat straw by the upflow anaerobic solid-state (UASS) process. Bioresource Technology, 124(3):321-327.

[30]Rathore, D., Nizami, A. S., Singh, A., \& Pant, D, 2016. Key issues in estimating energy and greenhouse gas savings of biofuels: challenges and perspectives, 3(2), 380-393.

[31] Sahn D E, Stifel D C, 2003. Urban-Rural Inequality in Living Standards in Africa. Journal of African Economies, 12(4):564-597.

[32]Tian Y S, 2016. China Rural Energy Development Status and Trends in 2015. Energy of China, 38(7):25-29.

[33] Tsinghua University, 2016. China Building Energy Efficiency Annual Research Report. China Architecture \& Building Press, Beijing. (In Chinese)

[34]UN, 2017. FAO database. http://statistics.amis-outlook.org/data/index.html (accessed 2017/07/04)

[35]Wei, Q., Yan, X. Y., Ye, J. H., Sun, Y. F., Wei, W., \& Zhang, Z. Z, 2011. Evaluation of biogas production from different biomass wastes with/without hydrothermal pretreatment. Renewable Energy, 36(12), 3313-3318.

[36]Xi L F.; Jian X Z.; Hu W J.; Yu W Y.; Gu Y J.; Cao Y, 2013. Application and Prospect of Distributed Energy in New Rural Power Grid. Journal of Agricultural Mechanization Research, (4):226-230. 
1 [37]Yue J Z.; Zhang J.; Xu G Z.; Yang S G.; Zhang B L, 2006. Correlation Analysis of Main 2 Components and Caloric Values of Corn Straws. Journal of Henan Agricultural Sciences, 35(9):303 32.

4 [38]Zeng X, Ma Y, Ma L, 2007. Utilization of straw in biomass energy in China. Renewable \& Sustainable Energy Reviews, 11(5):976-987.

[39]Zhang F.; Yang M H, 2010. Supply and demand analysis of rural distributed energy supplying mode. POWER SYSTEM PROTECTION AND CONTROL, 38(23):121-125.

[40]Zhang, L. X., Wang, C. B., \& Song, B. , 2013. Carbon emission reduction potential of a typical household biogas system in rural china. Journal of Cleaner Production, 47(5), 415-421.

10

[41]Zhang, Y. L., Gao, X. X., Wang, A. H., \& Zhao, L. X. , 2009. Life-cycle assessment for Chinese fuel ethanol demonstration projects. Renewable Energy Resources.

[42]Zhao L.; Leng Y W.; Ren H X.; Li H, 2010. Life Cycle Assessment for Large-scale Centralized Straw Gas Supply Project. JOURNAL OF ANHUI AGRICULTURAL SCIENCES, 38(34):1946219464.(In Chinese)

[43]Zhong, Y., Zhong, Y., Zeng, Q., Cai, Y., \& Chen, T, 2016. Method for producing synthesis natural gas using straw gas. 